\title{
Infection by Cryptosporidium parvum in renal patients submitted to renal transplant or hemodialysis
}

\author{
Infecção por Cryptosporidium parvum em renais crônicos \\ submetidos a transplante ou hemodiálise
}

\author{
Pedro Paulo Chieffi, Yvoty A.S. Sens, Maria Aparecida Paschoalotti, \\ Luiz Antonio Miorin, Hélio Gomes C. Silva and Pedro Jabur
}

\begin{abstract}
The frequency of infection by Cryptosporidium parvum was determined in two groups of renal patients submitted to immunosuppression. One group consisted of 23 renal transplanted individuals, and the other consisted of 32 patients with chronic renal insufficiency, periodically submitted to hemodialysis. A third group of 27 patients with systemic arterial hypertension, not immunosuppressed, was used as control. During a period of 18 months all the patients were submitted to faecal examination to detect C. parvum oocysts, for a total of 1 to 6 tests per patient. The results showed frequencies of C. parvum infection of $34.8 \%, 25 \%$ and $17.4 \%$, respectively, for the renal transplanted group, the patients submitted to hemodialysis and the control group. Statistical analysis showed no significant differences among the three groups even though the frequency of $\mathrm{C}$. parvum infection was higher in the transplanted group. However, when the number of fecal samples containing C. parvum oocysts was taken in account, a significantly higher frequency was found in the renal transplanted group.
\end{abstract}

Key-words: Cryptosporidiosis. Cryptosporidium parvum. Renal transplantation.

Resumo Determinou-se a freqüência de infecção por Cryptosporidium parvum em dois grupos de pacientes com doença renal, submetidos a imunossupressão. O primeiro grupo era constituído por 23 pacientes submetidos a transplante renal e o segundo por 32 indivíduos portadores de insuficiência renal crônica, periodicamente submetidos a hemodiálise. Um terceiro grupo de 27 pacientes com hipertensão arterial sistêmica, não imunossuprimidos, foi utilizado como controle. Os pacientes, acompanhados durante 18 meses, foram submetidos a exames parasitológicos para detecção de oocistos de C. parvum nas fezes, em quantidade que variou de 1 a 6 exames por paciente. Os resultados revelaram freqüências de infecção por C. parvum iguais a $34,8 \%, 25,0 \%$ e $17,4 \%$, respectivamente, para os pacientes submetidos a transplante renal, hemodiálise e os pertencentes ao grupo controle. Não se observaram diferenças significantes entre os três grupos embora note-se tendência a maior freqüência de infecção entre os pacientes submetidos a transplante renal. Todavia, quando se considerou o número de amostras fecais com presença de oocistos de C. parvum encontrou-se freqüência significativamente maior entre os pacientes transplantados.

Palavras-chaves: Cryptosporidiose. Cryptosporidium parvum. Transplante renal.

Tropical Medicine Institute of São Paulo, Brazil (LIM 06) and Medicine School of Santa Casa de São Paulo, Brazil.

Address to: Dr. Pedro P. Chieffi. Instituto de Medicina Tropical de São Paulo. Av. Dr. Enéas de Carvalho Aguiar 470, 05403-000 São Paulo, SP, Brasil. Fax: (5511) 3064-5132.

Recebido para publicação em 15/07/97. 
From the beginning of the eighties on, infection by Cryptosporidium parvum has been recognized as a frequent cause of enteric alterations, and less commonly extraintestinal disease in immunosuppressed patients, mainly those who have AIDS, with several grades of severity, depending on the level of involvement of their immune system 23 . Cryptosporidiosis has been observed even in non-immunosuppressed individuals, but without the same severity because of a self-limited clinical course ${ }^{18}$.

The consumption of food as well as the utilization of, and contact with, water contaminated by the oocysts of $C$. parvum, as well as contact with either animals or human beings infected by this coccidian are considered to be sources of Cryptosporidium infection 11 . The occurrence of intrahospital transmission of Cryptosporidium 12, as well as the vulnerability of patients submitted to either bone-marrow 716 or renal transplantation 23 has been reported.

Cryptosporidiosis shows a worldwide distribution and has been diagnosed at higher prevalence rates in developing countries2 23 . In Brazil it has frequently been found in AIDS patients 4 and in non-immunosuppressed diarrhoeal children15, but C. parvum oocysts have been found even in patients with nondiarrhoeal faeces 1325 .

In the present study we investigated the occurrence of $C$. parvum infection in renal immunosuppressed patients submitted either to renal transplantation or hemodialysis. Elsewhere we had analyzed the presence of other intestinal

\section{MATERIAL AND METHODS}

parasites in the same patients 9 .

Three groups of adult patients of both sexes seen at the Nefrology Clinic of the Department of Medicine, Medical School of Santa Casa de São Paulo (Brazil) from September 93 to April 95, were examined for the presence of $C$. parvum oocysts in the stool by staining with carbolfuchsin ${ }^{1}$ after concentration by the formol-ether technique ${ }^{14}$. The first group consisted of 23 renal transplanted patients kept in immunosuppression in order to avoid rejection; the second of 32 patients with chronic renal insufficiency immunosuppressed as a consequence of their disease and kept on hemodialysis, and the third one, considered as a control group, consisted of 27 patients with systemic arterial hypertension without any immunosuppression.

Each patient was submitted to different numbers of faecal examinations for the detection of $C$. parvum oocysts during a period

Table 1 - Number of faecal samples of each patient examined for detecting C. parvum oocysts.

\begin{tabular}{|c|c|c|c|c|c|}
\hline \multirow{2}{*}{ Group } & \multicolumn{3}{|c|}{ Number of samples } & \multicolumn{2}{|c|}{ Total } \\
\hline & 1 & $2-3$ & $4-6$ & samples & patients \\
\hline Transplanted & 11 & 5 & 7 & 58 & 23 \\
\hline Hemodialysis & 10 & 16 & 6 & 78 & 32 \\
\hline Control & 9 & 8 & 10 & 82 & 27 \\
\hline
\end{tabular}

\section{RESULTS}

No significative difference in the frequency of infection by $C$. parvum was found among groups, as shown in Table 2 (Chi square $=2.70$; $\mathrm{DF}=2 ; p=0.259$ ), although the difference between the transplanted group and the control group almost achieved significance $(p=0.09)$.
However, when the number of faecal samples that were positive for $C$. parvum oocysts was considered (Table 3 ) a significant difference was found between the transplanted group and the control group (Chi square $=5.77$; $\mathrm{DF}=1 ; p=0.016)$. 
Table 2 - Frequency of infection by C. parvum in all the studied groups.

\begin{tabular}{|c|c|c|c|c|c|}
\hline \multirow[t]{3}{*}{ Group } & \multicolumn{4}{|c|}{ Results } & \multirow[t]{3}{*}{ Total } \\
\hline & \multicolumn{2}{|c|}{ Positive } & \multicolumn{2}{|c|}{ Negative } & \\
\hline & $\mathrm{nr}$ & $\%$ & $\mathrm{nr}$ & $\%$ & \\
\hline Transplanted & 8 & 34.8 & 15 & 65.2 & 23 \\
\hline Hemodialysis & 8 & 25.0 & 24 & 75.0 & 32 \\
\hline Control & 4 & 17.4 & 23 & 82.6 & 27 \\
\hline
\end{tabular}

Table 3 - Number of positive faecal samples for C. parvum oocysts in all the patient groups.

\begin{tabular}{|c|c|c|c|c|c|}
\hline \multirow[t]{3}{*}{ Group } & \multicolumn{4}{|c|}{ Results } & \multirow[t]{3}{*}{ Total } \\
\hline & \multicolumn{2}{|c|}{ Positive } & \multicolumn{2}{|c|}{ Negative } & \\
\hline & $\mathrm{nr}$ & $\%$ & $\mathrm{nr}$ & $\%$ & \\
\hline Transplanted & 10 & 17.2 & 48 & 82.8 & 58 \\
\hline Hemodialysis & 8 & 10.3 & 70 & 89.7 & 78 \\
\hline Control & 4 & 4.9 & 78 & 95.1 & 82 \\
\hline
\end{tabular}

\section{DISCUSSION}

Infection by $C$. parvum has been considered as one of the most important causes of diarrhoea in immunocompetent children and as an important morbid agent, hardly controlled and, sometimes, uncontrollable, in immunosuppressed patients2 23.

Many times, especially when CD4+ cells counts are below 180 per $\mathrm{mm}^{3}$, cryptosporidiosis had been found to impair the clinical outlook of patients presenting congenital hypogammaglobulinemia, neoplasms, and mainly AIDS, or submitted to bone-marrow and solid organ transplantations3 671016192226 .

On the other hand, frequently C. parvum oocysts have been found in both asymptomatic and oligosymptomatic patients, especially children17 24 25, who, in addition to some synantropic animal species, are the major natural sources of cryptosporidiosis infection 11.

Experiments carried out on animals have shown either activation of latent Cryptosporidium infections or aggravation of mild infections by the prolonged use of immunosuppressive drugs 2021 . Thus, organ transplantation patients submitted to immunosuppression to avoid rejection could be considered as a group of risk for cryptosporidiosis 5 , as they are for other opportunistic infections. Indeed, there are some reports of the occurrence of severe diarrhoea caused by $C$. parvum infection in transplanted patients 7162226 . At the same time, asymptomatic or oligosymptomatic infections caused by this coccidian in transplanted patients or even in individuals immunosuppressed due to other causes, may often become exacerbated because of the impaired immune system of the host 8 .

Roncoroni et al22 detected 11 patients infected by Cryptosporidium among 14 who had presented diarrhoea after renal transplant. In another group of patients examined for Cryptosporidium oocysts before and after the renal transplant, they frequently found Cryptosporidium asymptomatic infections. In the present study, among 23 patients submitted to renal transplant $8(34.8 \%)$ were shedding C. parvum oocysts at least one of the stool samples examined during a period of 18 months (Tables 1 and 2). Most of these patients had no diarrhoea when they were eliminating $C$. parvum oocysts and they did not differ significantly from the control groups in terms of frequency of Cryptosporidium infection $(p=0.09)$. However, the number of stool samples that were positive for $C$. parvum oocysts was significantly higher in the transplanted patients when compared to the control group $(p=0.01)$, probably as a consequence of a larger number of infectious episodes or to the prolonged course of $C$. parvum infection in these patients.

Among the patients with chronic renal insufficiency submitted to hemodialysis, 25\% showed at least one faecal sample containing C. parvum oocysts and $10.3 \%$ of all the samples examined were positives (Tables 2 and 3 ). No significant differences were found between this group and the control group, suggesting that the level of immunosuppression in these patients was not sufficient to increase their risk of being infected by Cryptosporidium. 
In summary, the results of the present paper suggest that patients submitted to renal transplant should be considered as a group at risk for Cryptosporidium infection and that it would be worthwhile to periodically submit these patients and the medical staff to coprological tests for C. parvum oocysts in order to avoid intrahospital transmission22. Special care should be taken as well to prevent person-to-person transmission when there is someone infected in the transplantation section, since the available treatment of Cryptosporidium infection for immunosuppressed patients is not so efficient 1827 .

\section{REFERENCES}

1. Bronsdon MA. Rapid dimethylsulfoxide modified acidfast stain of Cryptosporidium oocysts in stool specimens. Journal of Clinical Microbiology 19:952953, 1984.

2. Current WL, Garcia LS. Cryptosporidiosis. Journal of Infectious Diseases 160:325-358, 1991.

3. Davis JJ, Heyman MB. Cryptosporisiosis and sinusitis in an immunodeficient adolescent. Journal of Infectious Diseases 158:648, 1988.

4. Dias RMDS, Mangini ACS, Torres DMAGV, Corrêa MOA, Lupetti N, Corrêa FMA, Chieffi PP. Cryptosporidiosis among patients with acquired immunodeficiency syndrome (AIDS) in the county of São Paulo, Brazil. Revista do Instituto de Medicina Tropical de São Paulo 30:310-312, 1988.

5. Flanigan TP. Human immunodeficiency virus infection and cryptosporidiosis: protective immune responses. American Journal of Tropical Medicina and Hygiene 50 (supl):29-35, 1994.

6. Flanigan TP, Whalen C, Turner J, Soave R, Toerner J, Havlir D, Kotler D. Cryptosporidium infection and CD4 counts. Annals of Internal Medicine 116:840-842, 1992.

7. Gentile G, Venditti M, Micozzi A, Caprioli A, Donelli G, Tirindelli C, Meloni G, Arcese W, Martino P. Cryptosporidiosis in patients with hematologic malignancies. Review of Infectious Diseases 13:842846, 1991.

8. Holley Jr HP, Thiers BH. Cryptosporidiosis in a patient receiving immunosupressive therapy. Possible activation of latent infection. Digestive Diseases Science 31:1004-1007, 1986.

9. Jabur P, Miorim LA, Siva HGC, Paschoalotti MA, Chieffi PP, Sens YAS. Criptosporidiose e outras enteroparasitoses em pacientes submetidos a transplante renal ou hemodiálise. Jornal Brasileiro de Nefrologia 18:239-242, 1996.
10. Jacyma MR, Parkin J, Goldin R, Baron JH. Protacted enteric cryptosporidial infection in selective immunoglobulin A and Saccharomyces opsonin deficiencies. Gut 31:714-716, 1990.

11. Juranek DD. Cryptosporidiosis: sources of infection and guidelines for prevention. Clinical Infectious Disease 21 (suppl I):557-561, 1995.

12. Koch KL, Phillips DJ, Aber RC, Current WL. Cryptosporidiosis in hospital personnel: evidence for person-to-person transmission. Annals of Internal Medicine 102:593-596, 1985.

13. Loureiro ECB, Linhares AC, Mata L. Acute diarrhoea associated with Cryptosporidium sp in Belém, Brazil. Revista do Instituto de Medicina Tropical de São Paulo 28:138-140, 1986.

14. Ma P, Soave R. Three-step stool examination for cryptosporidiosis in 10 homosexual men with protacted watery diarrhea. Journal of Infectious Diseases 147:824-828, 1983.

15. Mangini ACS, Dias RMDS, Grisi SJFE, Escobar AMU, Torres DMAGV, Zuba IPR, Quadros CMS, Chieffi PP. Parasitismo por Cryptosporidium sp em crianças com diarréia aguda. Revista do Instituto de Medicina Tropical de São Paulo 34:341-345, 1992.

16. Martino P, Gentile G, Caprioli A, Baldassarri L, Donelli G, Arcese W, Fenu S, Micozzi A, Venditti M, Mandelli F. Hospital-acquired cryptosporidiosis in a bone-marrow transplantation unit. Journal of Infectious Diseases 158:647-648, 1988.

17. Nimri LF, Batchoun R. Prevalence of Cryptosporidium species in elementary school children. Journal of Clinical Microbiology 32:1040-1042, 1994.

18. O' Donoghue PJ. Cryptosporidium and cryptosporidiosis in man and animals. International Journal for Parasitology 25:139-195, 1995.

19. Petersen C. Cryptosporidiosis in patients infected with the human immunodeficiency virus. Clinical Infectious Diseases 15:903-909, 1992.

20. Rehg JE, Hancock ML, Woodmansee DB. Characterization of cyclophosphamide-rat model of cryptosporidiosis. Infection and Immunity 55:26692674, 1987.

21. Rehg JE, Hancock ML, Woodmansee DB. Characterization of dexamethasone-treated model of cryptosporidial infection. Journal of Infectious Diseases 158:1406-1407, 1988.

22. Roncoroni AJ, Gomez MA, Mera J, Cagnoni P, Michel D. Cryptosporidium infection in renal transplant patients. Journal of Infectious Diseases 160:559, 1989. 
23. Ungar BLP. Cryptosporidiosis in humans (Homo sapiens). In: Dubey JP, Speer CA, Fayer R (eds) Cryptosporidiosis of man and animals, CRC Press Inc, Boston, p. 59-82, 1990.

24. Vuorio AF, Jokipii AM, Jokipii L. Cryptosporidium in asymptomatic children. Review of Infectious Diseases 13:261-264, 1991.

25. Weikel CS, Johnston LI, Souza MA, Guerrant RL. Cryptosporidiosis in Northeastern Brazil: association with sporadic diarrhea. Journal of Infectious Diseases 151:963-965, 1985.
26. Weisburger WR, Hutcheon DF, Yardley JH, Roche JC, Hillis WD, Charache P. Cryptosporidiosis in an immunosupressed renal-transplant recipient with $\lg \mathrm{A}$ deficiency. American Journal of Clinical Pathology 72:473-478, 1979.

27. Wittenberg DF, Miller NM, Van den Ende J. Spiramycin is not effective in treating cryptosporidium diarrhea in infants: results of a double-blind randomized trial. Journal of Infectious Diseases 159:131-132, 1989. 